\title{
Analisis faktor-faktor yang memengaruhi sikap dan tanggung jawab Mahasiswa Profesi Ners di Stase Komunitas
}

\author{
Nutrisia Nu'im Haiya \\ Fakultas Ilmu Keperawatan, Universitas Islam Sultan Agung, Indonesia \\ Coresponding Author: h41ya_nuim@yahoo.com
}

\begin{abstract}
Abstrak
Pendahuluan: Stase Komunitas merupakan salah satu rangkaian stase yang ada pada Program Profesi Ners Fakultas IImu Keperawatan UNISSULA. Yaitu praktik keperawatan yang dilakukan langsung di masyarakat, sehingga mahasiswa berinteraksi langsung dengan masyarakat. Tujuan: Pendidikan tinggi keperawatan mempunyai tujuan menghasilkan perawat yang professional. Dimana perguruan tinggi tersebut sangat berperan dalam membina sikap, pandangan dan kemampuan professional lulusan, sehingga diharapkan perawat mampu bersikap dan berpandangan professional, berwawasan keperawatan yang luas, serta mempunyai pengetahuan ilmiah keperawatan yang memadahi dan menguasai ketrampilan profesional dengan baik dan benar. Tujuan dari penelitian ini adalah menganalisa faktor yang mempengaruhi sikap tanggung jawab mahasiswa Profesi Ners Di Stase Komunitas. Metode: Penelitian ini menggunakan desain analitik, dengan jumlah responden 103 mahasiswa. Teknik pengambilan sempel menggunakan total sampling. Hasil: Penelitian didapatkan faktor-faktor yang mempengaruhi sikap tanggung jawab mahasiswa di satse komunitas yaitu; dosen idola, asal daerah, perasaan dan metode conference. Simpulan: Bahwa asal daerah, dosen idola, metode conference, dan perasaan dapat mempengaruhi sikap tanggung jawab mahasiswa di stase komunitas.
\end{abstract}

Kata kunci: Profesi ners; sikap tanggung jawab; stase komunitas

\section{Analyz factors affecting the responsibility of Professional Ners Students in The Community Stage}

\begin{abstract}
Introduction: Community Stage is one of the series of Stages in the UNISSULA Nursing Faculty Professional Nursing Program. Namely nursing practice carried out directly in the community, so students interact directly with the community. Nursing higher education aims to produce professional nurses. Where these tertiary institutions play an important role in fostering professional attitudes, views, and abilities of graduates, so that nurses are expected to be able to behave and have professional views, broad nursing insight, and have scientific knowledge of nursing that is good and has good and correct professional skills. The purpose of this study is to analyze the factors that influence the attitude of the responsibility of professional students at the Community stage. Methods: This research method uses analytic design, with the number of respondents 103 students. The sampling technique uses total sampling. Results: The results of the study found that the factors that influence the attitude of student responsibility in the community stage are; idol lecturer, regional origin, feelings and conference method. Conclusions: that regional origin, idol lecturers, conference methods, and feelings can influence student responsibility in the community stage.
\end{abstract}

Keywords: Professional profession;rResponsibility; community stage

How to Cite: Haiya, N.H. (2020). Analisis faktor-faktor yang mempengaruhi sikap dan tanggung jawab Mahasiswa Profesi Ners di Stase Komunitas. NURSCOPE: Jurnal Penelitian dan Pemikiran IImiah Keperawatan, 6(1), 9-14

\section{PENDAHULUAN}

Stase Komunitas merupakan salah satu rangkaian stase yang ada pada Program Profesi Ners Fakultas IImu Keperawatan UNISSULA. Di mana stase komunitas adalah praktik keperawatan yang dilakukan langsung di masyarakat, sehingga mahasiswa berinteraksi langsung dengan masyarakat (Nursalam \& Efendi, 2012). Dalam berinteraksi dengan masyarakat seringkali mahasiswa harus menata sikapnya dengan baik dan harus mempunyai tanggungjawab yang baik sehingga dapat membawa diri di 
masyarakat tempat praktik. Hal ini merupakan bekal ilmu tersendiri yang sangat dibutuhkan saat nanti benar-benar berada ditengah masyarakat ketika sudah lulus dari bangku kuliah. Pendidikan tinggi keperawatan mempunyai tujuan menghasilkan perawat yang professional. Dimana perguruan tinggi tersebut sangat berperan dalam membina sikap, pandangan dan kemampuan professional lulusan, sehingga diharapkan perawat mampu bersikap dan berpandangan professional, berwawasan keperawatan yang luas, serta mempunyai pengetahuan ilmiah keperawatan yang memadahi dan menguasai ketrampilan profesional dengan baik dan benar.

Hasil study yang telah dilakukan oleh Masrukhin (2013) didapatkan hasil proses pembentukan karakter sangat mempengaruhi cara pandang individu terhadap diri dan lingkungannya, yang tercermin dalam perilaku sehari-hari. Nasrudin, Herdiana, \& Nazudi (2015) menyatakan bahwa pengembangan model pendidikan karakter berdasarkan sifat fitrah manusia, menyatakan bahwa pengembangan model karakter tersebut diterima oleh dosen dan mahasiswa. Pernyataan Nasrudin tersebut didukung pula oleh study Kensiwi, Surarso, \& Suyitno (2013) pendidikan karakter dapat menumbuhkan niai-nilai karakter: tanggung jawab sehingga mampu meningkatkan pemahaman konsep peserta didik. Tujuan dari penelitian ini adalah menganalisa faktor yang mempengaruhi sikap tanggung jawab mahasiswa profesi ners di stase komunitas. Metode penelitian ini menggunakan desain analitik.

\section{METODE}

Desain penelitian yang digunakan dalam penelitian ini adalah penelitian analitik. Teknik pengambilan sampel menggunakan total sampling dengan jumlah responden 103 mahasiswa. Instrumen dalam penelitian ini ada 2 jenis instrument, yang terdiri dari 2 Angket dan 1 lembar observasi. Angket $A$ digunakan untuk mengetahui karakteristik responden (nama, jenis kelamin, umur, agama, asal, perasaan, dosen idola dan penilaian metode conference) dan angket B lembar ceklist skala Likert sikap tanggung jawab dari (Nursa'ban, 2013) yang telah dimodivikasi sesuai kebutuhan penelitian dan telah dilakukan uji validitas dengan nilai corrected item-total correlation $(>0,632)$ dan nilai reliabilitas Cronbach's Alpha 0,979 $(>0,60)$.

\section{HASIL DAN PEMBAHASAN}

Penelitian dilakukan di Fakultas IImu Keperawatan Universitas Islam Sultan Agung (UNISSULA) dengan 103 responden yang telah memenuhi kreterian sampel penelitian. Responden yang digunakan adalah mahasiswa Profesi Ners IX yang berada di Stase Komunitas. Pengambilan data penelitian dilakukan setelah mahasiswa menjalani Stase Komunitas yang berlangsung sekitar 6 pekan, pada pekan terakhir dilakukan pengambilan data penelitian.

Tabel 1. Diskripsi karakteristik responden berdasarkan umur, jenis kelamin, asal daerah dan Dosen idola $(\mathrm{N}=103)$

\begin{tabular}{lll}
\hline Variabel & $\mathbf{f}$ & $\mathbf{\%}$ \\
\hline Umur & & \\
21 tahun & 9 & $8,7 \%$ \\
22 tahun & 55 & $53,4 \%$ \\
23 tahun & 24 & $23,3 \%$ \\
24 tahun & 10 & $9,7 \%$ \\
25 tahun & 2 & $1,9 \%$ \\
27 tahun & 2 & $1,9 \%$ \\
28 tahun & 1 & $1,0 \%$ \\
Total & $\mathbf{1 0 3}$ & $\mathbf{1 0 0} \%$ \\
\hline Jenis Kelamin & & \\
Laki-laki & 16 & $15,5 \%$ \\
Perempuan & 87 & $84,5 \%$ \\
Total & $\mathbf{1 0 3}$ & $\mathbf{1 0 0} \%$ \\
\hline
\end{tabular}




\begin{tabular}{lll}
\hline Variabel & $\mathbf{f}$ & $\mathbf{\%}$ \\
\hline Asal daerah & & \\
Jawa & 62 & $60,2 \%$ \\
Luar Jawa & 41 & $39,8 \%$ \\
Total & $\mathbf{1 0 3}$ & $100 \%$ \\
\hline Dosen Idola & & \\
Pemberi Metode & 88 & $85,4 \%$ \\
Bukan Pemberi metode & 15 & $14,6 \%$ \\
Total & $\mathbf{1 0 3}$ & $100 \%$ \\
\hline Perasaan Kuliah di FIK & & \\
Menyenangkan & 94 & $91,3 \%$ \\
Biasa-biasa saja & 9 & $8,7 \%$ \\
Tidak menyenangkan & 0 & $0 \%$ \\
Total & $\mathbf{1 0 3}$ & $\mathbf{1 0 0} \%$ \\
\hline Metode conference & & \\
Baik & 90 & $87,4 \%$ \\
Cukup & 12 & $11,7 \%$ \\
Kurang & 1 & $1,0 \%$ \\
Total & $\mathbf{1 0 3}$ & $\mathbf{1 0 0} \%$ \\
\hline
\end{tabular}

Berdasarkan tabel 1. umur responden terbanyak pada 22 tahun sebanyak 55 orang $(53,4 \%)$, dan jenis kelamin terbanyak adalah perempuan sebanyak 87 orang $(84,5 \%)$, serta asal daerah terbanyak dari jawa sejumlah 62 orang $(60,2 \%)$. Untuk proses pembelajaran karakteristik dosen idola responden terbanyak adalah pemberi metode 88 orang $(85,4 \%)$, dan perasaan responden kuliah di FIK terbanyak menyenangkan 94 orang $(91,3 \%)$, serta penilaian responden pada metode conference terbanyak baik 90 orang $(87,4 \%)$.

Tabel 2. Diskripsi sikap tanggung jawab mahaiswa profesi Ners di Stase Komunitas $(\mathrm{N}=103)$

\begin{tabular}{lll}
\hline Variabel & $\mathbf{f}$ & $\%$ \\
\hline Sikap Tanggung Jawab & & \\
Sangat baik & 81 & $78,6 \%$ \\
Baik & 22 & $21,4 \%$ \\
Total & 103 & $\mathbf{1 0 0 \%}$ \\
\hline
\end{tabular}

Tabel 2. menggambarkan sikap tanggung jawab mahasiswa profesi ners di stase komunitas dengan jumlah terbanyak 81 orang $(78,6 \%)$ dengan hasil baik.

Tabel 3. Uji korelasi faktor-faktor yang memengaruhi sikap tanggung jawab mahasiswa dalam menjalankan tugas profesi pada Stase Komunitas ( $N=103)$

\begin{tabular}{lll}
\hline Variabel & $\boldsymbol{r}$ & $\begin{array}{l}\text { Signifikansi } \\
\boldsymbol{P} \text { Value }\end{array}$ \\
\hline Metode Conference & $-0,801$ & 0,000 \\
Usia & $-0,256$ & 0,257 \\
Jenis Kelamin & $-0,092$ & 0,710 \\
Daerah Asal & $-0,503$ & 0,042 \\
Dosen Idola & $-0,632$ & 0,008 \\
Perasaan kuliah di FIK & 0,625 & 0,012 \\
\hline
\end{tabular}

Tabel 3. menunjukkan bahwa fakto-faktor yang memengaruhi sikap tanggung jawab mahasiswa di stase komunitas adalah asal daerah, dosen idola, perasaan, dan metode conference merupakan faktor yang paling berpengaruh. 
Gambaran karakteristik penelitian ini menunjukkan responden yang paling banyak berada pada usia 22 tahun dengan jenis kelamin terbanyak perempuan dan terbanyak berasal dari daerah jawa. Serta dosen idola terbanyak responden adalah yang memberikan metode bimbingan dengan menggunakan metode conference dengan penilaian metode terbanyak baik, dan perasaan kuliah di Fakultas IImu Keperawatan terbanyak menyenangkan. Gambaran sikap tanggung jawab mahasiswa dalam penelitian ini menunjukkan sangat baik menjadi sikap tanggung jawab terbanyak, serta sebagian kecil menunjukkan sikap tanggung jawab baik dan tidak ada sikap tanggung jawab yang tidak baik.

Sikap tanggungjawab mahasiswa dalam menjalankan tugas profesi yang menjadi proses belajar mahasiswa profesi perawat selain untuk mendapatkan ilmu praktik langsung juga untuk membangun karakter yang baik profesi perawat professional. Sikap tanggungjawab yang sangat baik menandakan keberhasilan proses belajar dalam pembelajaran klinik/lapangan khususnya di stase komunitas. Karena Rasyidah, Pratiwi, \& Sulur (2011) menuturkan pengembangan karakter tanggung jawab dapat meningkatkan kognitif. Sedangkan Aprilia (2014) menjelaskan bahwa sikap tanggung jawab mahasiswa yang baik terhadap proses pembelajaranya didukung oleh metode pembelajaran yang baik pula. Jadi dukungan metode pembelajaran sangat perperan dalam peningkatan sikap tanggung jawab mahasiswa dalam proses belajar sehingga meningkatkan kognitif yang akan memperbaiki hasil belajar, menjadi lebih baik.

Hasil penelitian yang telah dilakukan umur, agama dan jenis kelamin tidak berpengaruh pada sikap tanggung jawab mahasiswa sedangkan daerah asal, dosen idola, perasaan dan metode conference berpengaruh pada sikap tanggung jawab mahasiwa. Namun dari beberapa faktor yang berpengaruh terhadap sikap dan tanggung jawab metode conference yang paling berpengaruh dengan $P$ Value 0,000 . Dalam penelitian ini dapat dikatakan umur, jenis kelamin dan agama dapat dikendalikan. Azwar (2015) menyampaikan kebudayaan tempat dimana individu tinggal mempunyai pengaruh besar terhadap terbentuknya sikap dari individu tersebut. Hal ini terkait dengan hasil penelitian ini bahwa daerah asal mempengaruhi sikap tanggung jawab mahasiswa walaupun dengan pengaruh yang tidak terlalu besar, sehingga dapat dikatakan ini tidak menjadikan hal yang berarti.

Azwar (2015) juga menyampaikan seseorang dalam bersikap dapat dipengaruhi orang lain di sekitar individu tersebut yang merupakan komponen sosial yang dapat mempengaruhi sikap. Seseorang yang dianggap penting, seseorang yang diharapkan persetujuan terhadap gerak tingkah dan pendapat individu, seseorang yang tidak ingin dikecewakan individu, seseorang yang berarti khusus dan lainlainnya dapat mempengaruhi pembentukan sikap seseorang terhadap sesuatu. Penelitian ini seluruh responden mempunyai dosen idola (orang yang dianggap berpengaruh) dalam dirinya di stase komunitas dengan mengidolakan dosen yang memberikan metode, jadi ada lebih dari sebagian responden mengidolakan dosen pemberi metode yaitu yang dalam proses bimbingannya menggunakan metode conference.

Pendidikan profesi ners diharapkan menghasilkan lulusan yang memiliki sikap, pengetahuan dan ketrampilan professional. Sehingga dalam proses pendidikannya disusun berdasarkan 5 hal, yaitu: penguasaan ilmu pengetahuan dan teknologi; menyelesaikan masalah secara ilmiah; sikap dan tingkah laku yang professional dengan menumbuhkan dan membina kemampuan bersikap, bertindak dan berfikir profesional; belajar aktif dan mandiri; dan menumbuhkan serta membina ketrampilan dan sikap di masyarakat dengan pengalaman yang dikembangkan di masyarakat (community based learning) (Endah \& Nurhidayah, 2016). Selain itu, perawat juga mempunyai tanggung jawab kepemimpinan menurut Ulrich (2004), karena perawat sangat kental sekali dengan kerja tim dalam penanganan masalah yang dihadapi klien baik di klinik keluarga maupun masyarakat. 
Praktik lapangan menuntut mahasiswa untuk berhadapan langsung dengan masalah yang akan diselesaikan dalam proses belajar mereka, seperti halnya yang terjadi saat pembelajaran di klinik. Pembelajaran dalam dunia nyata dalam artian praktik, membuat mahasiswa mengasah karakter dan tanggungjawab yang tinggi. Suparmini \& M.Nursa'ban (2012) menyampaikan pembelajaran berbasis masalah dapat meningkatkan nilai tanggung jawab mahasiswa. Yuwanto (2012) juga menjelaskan mahasiswa mendapatkan kemampuan yang tinggi dalam manajemen stress yang tidak didaptkan dalam proses belajar di kelas, dengan menggunakan experiental learning. Hal ini hampir serupa dengan pembelajaran yang dilakukan di stase komunitas.

Dosen merupakan figur bagi mahasiswa dalam bertidak dan bersikap. Penelitian ini dosen idola atau orang yang berpengaruh dapat mempengaruhi sikap tanggung jawab responden, hal ini ada hubungan dengan metode conference yang telah dilakukan, dengan metode tersebut mahasiswa merasa nyaman dan tentunya juga suka dengan seseorang yang memberikan metode tersebut. Dibuktikan mahasiswa yang mempunyai perubahan sikap tanggung jawab berada pada kategori sangat baik mengidolakan dosen yang sama dan merupakan pemberi metode conference tersebut. Kedekatan mahasiswa terhadap dosenya yang menjadikan salah satu alas an mahasiswa mengidolakan dosennya. Suryanti \& Hartini (2013) menjelaskan bahwa dosen mempunyai peranan yang sangat penting dalam proses pembelajaran mahasiswa, komunikasi yang efektif dan kedekatan dengan mahasiswa menjadi jembatan mahasiswa untuk dapat mengutarakan masalah pembelajaran yang dihadapi.

Demikian halnya dengan perasaan responden yang sebagian besar mempunyai perasaan menyenangkan kuliah di tempat mereka menimba ilmu saat ini (pengalaman pribadi), hal ini tentu tidak terlepas dari metode pembelajaran yang digunakan pada proses pembelajaran yang sedang berlangsung. Terlebih faktor perasaan ini tidak lebih berpengaruh dibandingkan dengan dosen idola, jelas ini ada kaitannya dengan metode conference yang dilakukan dalam proses pembelajaran. Dengan demikian faktor-faktor yang dapat mempengaruhi sikap tanggung jawab mahasiswa daerah asal, perasaan menjalani Kuliah di tempat penelitian di lakukan, dosen idola dan metode conference. Dan yang paling berpengaruh adalah metode conference yang di gunakan dalam bimbingan proses pembelajaran di stase komunitas. Menurut Vezeau (2016) metode pembelajaran conference dalam pembelajaran dilapangan bagi perawat merupakan sesuatu rancangan yang menarik yang dapat memenuhi pembelajaran mahasiswa secara terintegrasi antara konsep dan pengalaman praktik. Serta mendukung domain afektif dan pengembangan peran professional perawat. Maka oleh karenanya metode conference dalam penelitian ini dapat memberikan pengaruh yang cukup signifikan. Juga disampaikan Berkstresser (2016) menegaskan bahwa post conference yang merupakan lanjutan dari conference dapat membangkitkan proses berfikir kritis mahasiswa.

\section{SIMPULAN DAN SARAN}

Faktor-faktor yang memengaruhi sikap tanggung jawab mahasiswa profesi ners di stase komunitas yaitu dosen idola, daerah asal, perasaan dan pemakaian metode pembelajaran. Faktor yang paling berpengaruh adalah metode pembelajaran yang digunakan, yaitu metode conference.Peneliti selanjutnya dapat meneliti lebih lanjut fokus setiap faktor yang terkait, dan dapat meneliti hasil evaluasi capaian pembelajaran dan sikap tanggung jawab mahasiswa.

\section{DAFTAR PUSTAKA}

Aprilia, N. (2014). Peningkatan Keaktifan dan Tanggung Jawab Belajar Mahasiswa Melalui Penggunaan Model Cooperative Learning Tipe Two Stay Two Stray Pada Kegiatan Lesson Study Mata Kuliah Perkembangan Peserta Didik . 769-775.

Azwar, S. (2015). Sikap Manusia. Yogyakarta: Pustaka Pelajar.

Berkstresser, K. (2016). The use of online discussions for post-clinical conference. Nurse Education in 
Practice, 16(1), 27-32. https://doi.org/10.1016/j.nepr.2015.06.007

Endah, R., \& Nurhidayah. (2016). Pendidikan Keperawatan. (9). Retrieved from https://books.google.co.id/books?id=U6ApDgAAQBAJ\&printsec=frontcover\&dq=konsep+lansia . pdf+2018\&hl=id\&sa=X\&ved=2ahUKEwjYo6WXObDqAhWDxDgGHZNUCDEQuwUwA3oECAEQCA $\# v=$ onepage $\& q \& f=$ false

Kensiwi, F., Surarso, B., \& Suyitno, H. (2013). Pembelajaran Model Kooperatif Learning Tipe TSTS dengan Pendekatan Humanistik bermuatan Pendidikan Karakter Materi Bilangan Kompleks. 2(1), 76-83.

Masrukhin, A. (2013). Model Pembelajaran Character Building dan Implikasinya Terhadap Perilaku Mahasiswa. Humaniora, 4(2), 1229. https://doi.org/10.21512/humaniora.v4i2.3566

Nasrudin, Herdiana, I., \& Nazudi, N. (2015). Pengembangan Model Pendidikan Karakter Berdasarkan Sifat Fitrah Manusia. Jurnal Pendidikan Karakter, O(3), 264-271. https://doi.org/10.21831/jpk.v0i3.5631

Nursa'ban, M. (2013). Peningkatan Sikap Tanggung Jawab Dan Kemandirian Belajar Mahasiswa Melalui Metode Tutorial Di Jurusan Pendidikan Geografi. Jurnal Cakrawala Pendidikan, 3(3), 432-443. https://doi.org/10.21831/cp.v3i3.1630

Nursalam, \& Efendi, F. (2012). Pendidikan dalam Keperawatan. Jakarta: Salemba Medika.

Rasyidah, U. H., Pratiwi, R., \& Sulur. (2011). Pengembangan karakter tanggung jawab, kejujuran, tekun/gigih dan peningkatan hasil belajar kognitif fisika matematika ii melalui perkuliahan terpadu. Prosiding Seminar Nasional Penelitian, Pendidikan Dan Penerapan MIPA, 247-254.

Suparmini, \& M.Nursa'ban. (2012). Implementasi Nilai-nilai Kejujuran dan Tanggungjawab dalam Perkuliahan di Jurusan Pendidikan Geografi UNY (p. 20). p. 20.

Suryanti, H. H. S., \& Hartini, S. (2013). Peningkatan Kedisiplinan Kuliah Melalui Konseling Kelompok pada Mahasiswa Semester III Program Study Bimbingan dan Konseling FKIP UNISRI. 1-13.

Ulrich, B. (2004). Leadership: the professional responsibility of all RNs. Nephrology Nursing Journal: Journal of the American Nephrology Nurses' Association, 31(4), 364-365.

Vezeau, T. M. (2016). In defense of clinical conferences in clinical nursing education. Nurse Education in Practice, 16(1), 269-273. https://doi.org/10.1016/j.nepr.2015.10.006

Yuwanto, L. (2012). Pendidikan Karakter Melalui PeerGroup Camp. 164-174. Retrieved from https://publikasiilmiah.ums.ac.id/handle/11617/1514 